Equalita, Vol. 1 Issue 1, Agustus 2019

Avaliable online at http://syekhnurjati.ac.id/jurnal/index.php/equalita/article/view/5158

Diterbitkan oleh Pusat Studi Gender dan Anak LP2M IAIN Syekh Nurjati Cirebon, Indonesia

\title{
KAJIAN GENDER DALAM PEMBELAJARAN ILMU PENGETAHUAN SOSIAL (Perempuan Berkarakter Perempuan Pendidik Di Jurusan Tadris Ilmu Pengetahuan Sosial IAIN Syekh Nurjati Cirebon)
}

\section{Ratna Puspitasari}

ratnapuspitasari@syekhnurjati.ac.id

IAIN Syekh Nurjati Cirebon

• Received: 03 Maret 2019 • Accepted: 01 Agustus 2019 •Published online: 30 Agustus 2019

Abstract: The large gap between the goalsand the reality of equal rights is yhe condition of some Indonesian women. The disadvantaged position of Indonesian women and the continuing nasional education system indicate that Indonesia faces a long road to meet the goals of the United Nation millennium on gender equality and education sustainability. The number of Social Studies Tadris of Tarbiyah Faculty and Teacher Training IAIN Syekh Nurjati Cirebon who are still active in lectures are 520 people divided into female students for the 2019/2020 academic year 427 people while the number of male students as whole is a number of 193 people are both quantitative and qualitative potential for the Social Studies Tadris development to develop a gender equality-based curriculum with the representation of gender equality study subjects in social studies learning. The study of gender equality in social studies learning is not just a learning of transfer of values including values related to gender issues

Keyword: equality, gender, education

Abstrak: Kesenjangan yang besar antara tujuan dan kenyataan mengenai persamaan hak atas pendidikan merupakan kondisi sebagian perempuan Indonesia. Posisi perempuan Indonesia yang tidak menguntungkan dan terus berlangsungnya sistem pendidikan nasional menandakan bahwa Indonesia menghadapi jalan yang panjang untuk memenuhi tujuan milenium PBB tentang kesetaraan gender dan keberlanjutan pendidikan. Jumlah mahasiswa Tadris Ilmu Pengetahuan Sosial Fakultas Ilmu Tarbiyah dan Keguruan IAIN Syekh Nurjati Cirebon yang masih aktif dalam perkuliahan sejumlah 520 orang terbagi dalam mahasiswa berjenis kelamin perempuan untuk tahun ajaran 2019/2020 sejumlah 427 orang sementara jumlah mahasiswa berjenis kelamin laki-laki secara keseluruhan adalah sejumlah 193 orang merupakan potensi secara kuantitatif maupun kualitatif bagi jurusan Tadris IPS untuk mengembangkan kurikulum berbasis kesetaraan gender dengan keterwakilan mata kuliah Kajian Kesetaraan Gender dalam PIPS. Kajian kesetaraan gender dalam PIPS bukan hanya merupakan seperangkat urutan pembelajaran, namun menjadi salah satu bahan kajian untuk setiap bentuk pengetahuan, dengan segenap instrumen transfer nilai yang paling efektif termasuk didalamnya adalah nilai kesetaraan gender dalam lingkup pendidikan.

Keyword: kesetaraan, gender, pendidikan. 


\section{A. PENDAHULUAN}

Berdasarkan data Organisation for Economic Cooperation and Development (OECD)sebagaimana dikutip Okezone akhir tahun 2018 menyebutkan, angka putus sekolah di Indonesia menduduki peringkat nomor dua di dunia, Indonesia dengan tingkat distribusi pendidikan rerata bawah.

Tingkat pendidikan kaum wanita di Indonesia mengalami peningkatan dalam kurun lima tahun terakhir ini. Berdasarkan komparasi data yang dikeluarkan oleh Biro Pusat Statistik dari tahun 2010 sampai 2015, terdapat deskripsi angka yang menjelaskan adanya perkembangan pesat ke tingkat yang lebih tinggi di wilayah perdesaan sampai wilayah perkotaan. Hal yang menakjubkan bahwa wanita berpendidikan setaraf sarjana di perdesaan ternyata mengalahkan jumlah lelaki perdesaan yang berpendidikan setaraf sarjana.

Dari jumlah keseluruhan penduduk Indonesia, kaum wanita di daerah perdesaan yang berpendidikan setingkat sarjana saat tahun 2015 berada di kisaran 3,37 \%. Sementara itu kaum pria berada di kisaran angka 3,14 \%. Di wilayah perkotaan sendiri jumlah itu mengalami peningkatan tajam. Apabila saat tahun 2010 kaum wanita yang memiliki tingkat pendidikan setara sarjana berada di kisaran angka 7, $96 \%$, maka pada tahun 2015 meraih prosentase di kisaran 10,72 \%. Meski jika dibandingkan kaum pria masih tertinggal karena kaum pria berijasah sarjana ada di kisaran 11,32 \%.

Survei yang dilakukan Pusat Data dan Statistik Pendidikan (PDSP) Kementrian Pendidikan dan Kebudayaan pada tahun 2013 menjelaskan prosentase jumlah perempuan pendidik pada perguruan tinggi berada di kisaran 40,58 persen, sementara itu laki-laki pendidik di perguruan tinggi sejumlah 59,42 persen. Kementrian Pendidikan dan Kebudayaan menganalisa pendapat yang menyebutkan wanita sesungguhnya hanya memiliki tanggung jawab terhadap urusan rumah tangga atau domestik sehingga kurang memotivasi kaum perempuan dalam melanjutkan pendidikannya ke tingkat magister bahkan doktoral yang ternyata ditemukan di banyak Negara berkembang lainnya seperti di Indonesia (Mansour, 1997).

Di negara-negara maju sekelas Amerika Serikat sekalipun, prosentase jumlah wanita yang menempuh pendidikan setingkat doktoral ternyata lebih sedikit dibandingkan jumlah pria yang menempuh pendidikan doktoral. Hasil penelitian yang dilakukan oleh Survei National Science Fondation dalam kurun waktu 2010 sampai 
Ratna Puspitasari

dengan 2014 menunjukkan adanya sejumlah 72.446 wanita peraih gelar doktor dan sejumlah 104.425 orang pria yang telah meraih gelar doktor. Di sebagian besar wilayah di dunia, pendidikan kaum wanita telah diperjuangkan sejak dulu termasuk perjuangan bagi kaum perempuan di Indonesia.

R.A. Kartini merupakan salah seorang pejuang yang terkenal ulet dalam memperjuangkan hak pendidikan bagi kaumnya. Meskipun demikian, dalam kenyataannya pendidikan bagi kaum perempuan belum merata di Indonesia baik secara kualitas maupun kuantitas. Oleh karena kuatnya tradisi patriarkhi banyak wanita yang dalam kesempatan meraih pendidikan tidak dapat mengenyam pendidikan yang lebih tinggi tingkatannya. Kondisi ekonomi serta budaya patriarkhi membelenggu kaum perempuan pada masa awal abad ke 20.

Padahal, menurut psikolog Pendidikan, Martha (2019), pendidikan mampu menjadi peluang bagi kaum perempuan untuk meningkatkan taraf kesejahteraan hidup perempuan dan keluarganya. Melalui pendidikan yang tinggi, wanita mampu membekali ilmu bagi diri dan lingkungan sosialnya. Kaum wanita dianggap mampu meningkatkan derajat hidupnya meskipun seringkali terbagi beban di ranah publik dengan ranah domestik atau rumah tangga saat ia menikah dan berkeluarga. Hal tersebut bukan menjadi kendala untuk perempuan menggapai pendidikan setinggi-tingginya. Hal ini disebabkan alasan utama bahwa pendidikan menjadi dasar kehidupan seluruh manusia.

Manusia menerima ilmu pengetahuan, teknologi dan informasi guna mengembangkan diri dan lingkungannya melalui jalur pendidikan. Hal ini didasari alas an bahwa misi utama bidang pendidikan adalah upaya menyiapkan peserta didik agar mampu membuka diri untuk bertahan hidup (to make a living), upaya mengembangkan hidup yang lebih memiliki makna (to lead ameaningfull life) serta memuliakan kehidupan (to ennoble life) (Idris, 2004). Kemudian, salah satu tujuan pendidikan yaitu bagaimana untuk mewujudkan suatu masyarakat yang adil, dengan tidak mendiskriminasikan jenis kelamin.

Namun dalam kenyataannya sering kali terdapat diskriminasi dalam aspek pendidikan yang mewajibkan beberapa daya upaya guna mengatasi persoalan, salah satu diantaranya adalahmelalui perumusan kurikulum yang berperspektif gender. Kurikulum merupakan pengembangan visi misi institusi pendidikan yang berkeinginan melahirkan golongan pendidikan. Kurikulum Kajian Kesetaraan Gender dalam PIPS di Perguruan Tinggi lebih didasarkan pada asumsi bahwa wanita dan pria setara dalam pendidikan, dan memiliki kesempatan setara untuk memperoleh pendidikan. 
Dalam rutinitas kegiatan harian, semua pihak selalu berkaitan erat dengan gender karena kemunculan gender merupakan akibat dari munculnya konstruk social yang berlangsung di masyarakat itu sendiri. Sebenarnya, gender muncul sebagai perbedaan pada ranah yang bukan tergolong aspek biologis dan tidak digolongkan sebagai kodrat Tuhan. Konsep tentang gender dapat dibedkan dalam dua pengertian yaitu gender dengan jenis kelamin (seks). Perbedaan jenis kelamin di antara kaum wanita dengan kaum pria tidak mengalami perubahan dan hal tersebut menjadi ketentuan biologis.Sedangkan gender merupakan bentuk perbedaan perilaku yang melibatkan kaum wanita berbeda dengan kaum pria yang dibentuk oleh proses sosial. Dengan demikian, perbedaan secara non kodrati ini dibangun melewati proses social dan budaya yang panjang dan melelahkan.

Bias gender dalam aspek pendidikan sudah berlangsung lama serta diisosialisasikan dalam proses maupun sistem pendidikan di lembaga persekolahan dan dalam lingkungan keluarga. Bangunan dominasi budaya patriarkhi di negeri ini mengajarkan kepada siswa tentang apa yang layak dan tidak layak dilaksanakan oleh kaum laki-laki dan apa yang tidak layak dilakukan oleh perempuan (Mansour, 1997). Tidak sedikit perempuan yang masih berusia sekolah terpaksa harus bekerja, baik itu sebagai pelayan toko atau buruh pabrik. Dengan latar belakang keadaan ekonomi yang serba kekurangan, hal ini mendorong orang tua untuk memaksa anak perempuannya agar berhenti sekolah dan bekerja dengan harapan meningkatkan taraf ekonomi keluarga. Dengan kondisi seperti ini, orang tua cenderung untuk merelakan anak perempuannya agar bekerja untuk untuk membantu orang tua memenuhi nafkah keluarga sementara itu anak laki-laki tetap bersekolah (Idris, 2004).

Kaum laki-laki dianggap superior terutama dalam menuntut ilmu dengan alasan kaum laki-lakilah nantinya yang akan menghidupi seluruh keluarganya, Sedangkan kaum wanita tetap berkutat di ranah domestik atau rumah tangga. Dan pandangan seperti inilah maka meraih pendidikan yang lebih tinggi dianggap kurang diperlukan oleh kaum wanita. Stereotipe model seperti itulah yang terlihat diskriminatif dan sangat tidak memihak pada jenis kelamin tertentu, khususnya untuk pihak perempuan. Kaum perempuan mengalami perlakuan yang tidak berpihak terutama dalam meraih kesempatan pendidikan. Di sisi lain, kaum wanita dieksploitasi agar mau bekerja atau dipekerjakan untuk membantu ekonomi keluarga, meskipun seumuran mereka masih menikmati masa kanak-kanak bahkan sigolongkan dalm usia di bawah umur (Muawanah, 2009). 
Ratna Puspitasari

Jumlah mahasiswa Jurusan TIPS FITK IAIN Syekh Nurjati Cirebon yang masih aktif dalam perkuliahan sejumlah 520 orang terbagi dalam mahasiswa berjenis kelamin perempuan untuk tahun ajaran 2019/2020 sejumlah 427 orang sementara jumlah mahasiswa berjenis kelamin laki-laki secara keseluruhan adalah sejumlah 193 orang merupakan potensi secara kuantitatif maupun kualitatif bagi jurusan Tadris IPS untuk mengembangkan kurikulum berbasis kesetaraan gender dengan keterwakilan mata kuliah Kajian Kesetaraan Gender dalam PIPS.

Artikel ini mencoba menganalisa sejauh mana Kajian Kesetaraan Gender dalam PIPS Mampu Menciptakan Perempuan Berkarakter Perempuan Pendidik."

\section{B. PEMBAHASAN KeSETARAAN GENDER DALAM PERGURUAN TINGGI}

Jenis Secara tersirat muncul fenomena bahwa rendahnya kualitas pendidikan dari tingkat dasar sampai perguruan tinggi diakibatkan oleh adanya diskriminasi gender dalam pembelajaran. Setidaknya terdapat tiga hal terkait permasalahan gender secara umum yaitu:

1. Akses

Akses dalam hal ini adalah fasilitas pendidikan yang susah diraih. Misalnya, terdapat sejumlah besar sekolah dasar dan madrasah ibtidaiyah di tiap-tiap kecamatan namun bagi pendidikan setingkat SMP/MTs, SMA/ MA yang sangat sedikit dan tak mampu menampung sejumlah besar siswa dan dalam lokasi yang sangat sulit dan jauh untuk ditempuh. Dengan alasan inilah maka banyak orang tua melarang anak gadisnya untuk bersekolah di tempat yang jauh. Secara tidak langsung hal ini memaksa anak perempuan tinggal di rumah (Mansour, 1997). Belum lagi banyaknya tugas domestik yang ditanggung anak gadis untuk meneyelesaikan segenap pekerjaan rumah tangga sehingga mereka kesulitan keluar dari rumah. Penumpukan beban domestik ini juga menjadi indikator banyak anak gadis yang putus sekolah.

2. Partisipasi

Partisipasi didalamnya mencakup bidang studi maupun statistik pendidikan.Dalam sistem sosial dan budaya di Indonesia, masih bertahan sejumlah budaya warisan nenek moyang yang menempatkan peran utama perempuan ada di ranah domestik, sehingga yang sering terjadi adalah hambatan yang dihadapi anak gadis dalam mendapat peluang yang lebih terbuka dalam menjalani sekolah formal (Mansour, 1997). Hal yang seringkali menjadi keluhan adalah keterbatasan keuangan keluarga sehingga anak lakilaki mendapat prioritas dalam menempuh pendidikan. Pada umumnya, hal ini berkaitan 


\section{Ratna Puspitasari}

dengan tugas kaum laki-laki di kemudian hari saat menjadi dewasa dan berkeluarga akan berperan sebagai pemimpin rumah tangga dan menanggung nafkah keluarga.

3. Manfaat beserta penguasaan

Kondisi riil di lapangan menunjukkan masih banyaknya angka buta huruf di wilayah Indonesia ternyata dipenuhi oleh kaum wanita. Data yang dimunculkan Biro Pusat Statistik tahun 2003, menjelaskan dari sebanyak penduduk yang buta aksara umur 10 tahun lebih terdapat sejumlah 15.686 .161 orang, di mana sejumlah 10.643.823 penduduk diantaranya atau 67,85 \% merupakan wanita. Pendidikan bukan hanya proses pembelajaran, namun menjadi salah satu bahan kajian bagi seluruh pengetahuan oleh sebab itu instrument efektif transfer nilai yang dianut termasuk didalamnya nilai yang berhubungan dengan isu gender. Oleh sebab itu, pendidikan menjadi saeana sosialisasi kebudayaan yang berlangsung secara formal diantaranya di sekolah maupun di perguruan tinggi.

Tingkah laku yang muncul pada kehidupan sekolah atau perguruan tinggi diantaranya hubungandosen dengan dosen, dosen dengan mahasiswa, guru dengan guru, guru dengan murid, murid dengan murid, di dalam maupun di luar kelas saat proses pembelajaran berlangsung maupun di luar pembelajaran sehingga memunculkan konstruksi gender yang terbangun sejak dini (Muawanah, 2009). Selain hal tersenut, penataan posisi duduk siswa, penataan barisan, kegiatan upacara selalu terkait dengan konstruk yang dibangun sejak dulu. Peserta didik laki-laki ditempatkan di posisi yang paling strategis seperti menjadi pimpinan OSIS, menjadi ketua kelas, pimpinan diskusi kelas, maupun dalam menentukan kesempatan menyampaikan gagasan (Muawanah, 2009). Kondisi ini memunculkan banyaknya ketimpangan gender dalam proses pendidikan di sekolah.

Menurut Idris (2004) dengan semakin merendahnya tingkat pendidikan maka makin memperbesar tingkay kesenjangan gender dalam sistem pengupahan.Ada kecenderungan dari perbandingan pengupahan pria dengan wanita adalah 60,46 persen dengan 39,54 persen, di mana ketimpangan gender dalam pengupahan untuk pekerja laki-laki dan perempuan berpendidikan rendah adakah 65,68 persen dengan 35,32 persen. 
Ratna Puspitasari

\section{Pendidikan Berkeadilan Gender}

Dalam pasal 26 Deklarasi HAM dijelaskan bahwa semua warga negara berhak mendapatkan pendidikan yang layak sehinggapada dasarnya pendidikan tidak saja dianggap dan disebut sebagai sebuah unsur pokok dalam upaya mencerdaskan kehidupan bangsa namun juga sebagai hasil konstruksi sosial sehingga pendidikan mempunyai andil terbentuknya relasi gender pada masyarakat (Mansour, 1997).

Pendidikan sewajarnya menyasar kebutuhan dan sesuai dengan perkembangan jaman, yaitu kualitas yang berkaitan dengan keimanan serta hidup dalam iman dan taqwa yang sangat kokoh, memahami, menghayati dan menerapkan akar budaya bangsa, memiliki wawasan luas dan komprehensif, menguasai bidang pengetahuan, serta ketrampilan kompetitif sehingga mampu mengantisipasi perkembangan, mampu berpikir analitik, terbuka pada hal-hal baru, bersikap mandiri, selektif, memiliki kepedulian sosial yang besar sehingga mampu berprestasi (Muawanah, 2009). Kaum wanita dalam bidang pendidikan diarahkan untuk memperoleh kualifikasi tersebut sesauai dengan bidang kemampuan serta keinginannya.

Departemen Pendidikan dan Kebudayaan berupaya menjawab rumor itu melalui inovasi kurikulum yang terakomodasi dalam kurikulum 2004 dengan kegiatan pengaplikasian bahan ajar terkait isu kesetaraan genderdalam masyarakat yang berdampak pada kurang optimalnya sumber daya manusia dengan memiliki keunggulan di seluruh bidang tanpa mempertimbangkan jenis kelamin (Muawanah, 2009).

Dengan kondisi seperti ini, selayaknya pendidikan mampu memberi mata pembelajaran yang disesuaikan dengan minat dan bakat kaum wanita, bukan sekedar diarahkan pada pendidikan agama dan ekonomi keluarga, namun juga permasalahan pertanian maupun ketrampilan lain (Mansour, 1997). Pendidikan tersebut sangat membantu kaum wanita dalam segala hal sehingga dapat dijadikan nilai yang sangat besardan menjadi langkah pertama dalam memperjuangkan persamaan sesungguhnya (Ahmad, 2013).

\section{Membangun Pendidikan dengan Perspektif Gender di Jurusan TIPS}

Lembaga pendidikan tinggi menjadi salah satu media penting dalam membangun budaya responsif gender. Hal ini muncul disebabkan eksistensi pendidikan tinggi dalam berperan secara signifikan untuk membangun budaya dan kebudayaan. Terdapat beberapa landasan pemikiran yang mendasari bahwa lembaga pendidikan tinggi 
Ratna Puspitasari

seharusnya dijadikan wahana pokok dalam membangun budaya responsif gender (Ahmad, 2013).

Pertama, lembaga pendidikan tinggi merupakan sumber pengetahuan yang bertugas mengkaji dan mentransformasikan pengetahuan dengan mendesiminasi gagasan nilai baru pada warga (Muawanah, 2009). Reproduksi ilmu pengetahuan, faham dan doktrin dilaksanakan lewat kebijakan maupun atmosfer akademik serta atmosfir atmosfer di lingkungan kerja.

Kedua, lembaga perguruan tinggi menjadi wadah institusional bagi semua sivitas akademik baik pria maupun wanita untuk mengejawantahkan setiap potensi, mengaktualisasikan, serta mendefinisikan identitas diri. Ketiga, strategi pengarusutamaan gender dalam pembangunan adalah bentuk kebijakan yang akan diimplementasikan melalui institusi negara termasuk lembaga pendidikan tinggi di bawah Kementerian Ristek dan Kemenag (Ahmad, 2013). Pengarusutamaan gender dalam pendidikan dengan implementasi pengampuan mata kuliah Kesetaraan Gender bukanlah sebuah program pembelajaran yang semata-mata ditambahkan secara khusus (add-on). Salah satu strategi utama dan tahap awal dlam membangun kesetaraan gender di lembaga pendidikan tinggi dengan menjadikan sudut pandang kesetaraan gender sebagai arus utama. Proses ini wajib dilakukan di semua lini dan tahap penyelenggaraan pendidikan, diawali perencanaan, penganggaran, implementasi, evaluasi, dan monitoring program. Menjadikan perspektif gender sebagai arus pokok dengan mempertimbangkan perbedaan, kebutuhan, pengalaman serta aspirasi kaum pria dan wanita (KPPPA: 2010).

Jurusan Tadris IPS merupakan salah satu jurusan yang ada di bawah naungan perguruan tinggi keagamaan Islam di Cirebon sudah sejak 2010 menetapkan mata kuliah Kajian Kesetaraan Gender dalam PIPS sebagai salah satu mata kuliah yang menjadi penguatan dengan sistem perencanaan, proses dan hasil perkuliahan yang sensitivitas gender di Kementrian Agama. Peluang untuk menyelesaikan permasalahan pendidikan di masyarakat yang tidak adil gender sekaligus menjadi tantangan yang harus dijawab dengan berbagai langkah nyata.

Kurikulum pembelajaran IPS berbasis kesetaraan gender merupakan salah satu bentuk kepercayaan yang menjadi tanggung jawab pengampu mata kuliah Kajian Kesetaraan gender dalam PIPS sehingga dapat mengemban tugas sebagai motor penggerak promosi, sosialisasi serta pendampingan proses perencanaan, pembelajaran 
Ratna Puspitasari

dan hasil pembelajaran yang memiliki kepedulian pada kesetaraan gender di lingkungan IAIN Syekh Nurjati Cirebon.

Ciri utama dari mata kuliah Kajian Kesetaran Gender dalam PIPS adalah memiliki perencanaan, proses dan hasil belajar dengan mempertimbangkan kebutuhan pria dan wanita memberi manfaat bagi keduanya. Perlu dipahami bahwa gender tak selamanya identik dengan wanita. Pada kondisi ini itikad baik political will pimpinan sebagai pengambil kebijakan menjadi terwujud dalam mengantarkan kesuksesan program penerapan kurikulum berbasis kesetaraan gender di jurusan TIPS. Hal yang muncul dalam kajian ini adalah tidak adanya dominasi perempuan pada level pemegang kontrol menjadikan responsivitas dan sensitivitas gender otomatis melekat pada kebijakan dan program yang dilaksanakan. Keinginan kuat dari pengampu kebijakan kurikulum di tingkat jurusan menjadi terimplementasi bermakna dengan dukungan infrastruktur, focal point, dan partisipasi semua pihak, serta budaya akademik dan budaya kerja di IAIN Syekh Nurjati Cirebon. Diharapkan dengan adanya Kurikulum Berbasis Kesetaraan Gender di Jurusan Tadris IPS ini disertai political will yang kuat mampu mewujudkan kebijakan konstruktif yang membangun budaya responsif gender. Jika terlaksana, pilot project berjalan secara konseptual, sistematis, dan kontinu.

Jika sekolah maupun perguruan tinggi menempuh jalan sebaga pelestari nilai-nilai, sementara hasil pemikiran produktif berkolaborasi dengan kebutuhan masyarakat maka salah satu tugas Jurusan TIPS tidak membiarkan ketidakadilan tertutup oleh kesadaran palsu yang berlangsung di masyarakat. Sebaliknya sikap kritis dan memotivasi masyarakat kampus dan sekitarnya untuk mengubah stereotipe gender yang sering terbungkus kesadaran palsu sekaligus mentransformasikannya sebagai implementasi yang lebih berpihak pada keadilan dan kesetaraan gender utamanya perempuan.

\section{Analisis Gender di Lembaga Perkuliahan dan Sekolah}

Guna melaksanakan perubahan dalam lembaga pendidikan, pendidik tidak hanya mendasarkan diri pada asumsi-asumsi saja, namun selayaknya didasarkan data-data yang lebih konkrit daripada survay, pencarian, penelitian yang dianalisis secara kritis melalui lembaga pendidikan. Data-data di atas selanjutnya dijadikan pedoman dalam dalam melangkah dan menetapkan kebijakan-kebijakan strategis dalam melaksanakan perubahan-perubahan yang diperlukan. Pengamatan tersebut sebaiknya ditujukan pada bagian-bagian yang tergenderkan pada sebuah institusi organisasi maupun lembaga seperti halnya: ideologi dan tujuan, sistem nilai yang telah dikembangkan, dibangunnya struktur, sistem manajerial, jos descriptions, pengaturan tata letak bangunan, istilah dan 
Ratna Puspitasari

ungkapan, keterkaitan dengan kekuasaan, penggunaan lambang atau simbol, kesemuanya menunjukkan sinyal seberapa jauh lembaga pendidikan itu tergenderkan.

\section{Dosen,Guru/Pendidik sebagai Pilar}

Dosen dan guru mempunyai sense of gender sehingga yang diupayakan untuk memperoleh akses pada dasar-dasar pengetahuan dan pendidikan keadilan dan kesetaraan gender lebih awal, guna mengubah mind set untuk mengubah pola pikir dan nurani terhadap persoalan yang ada. Jika pendidik telah memperoleh akses yang cukup terkait pengetahuan tentang gender, selanjutnya komitmen menjadi landasan terpenting dalam membangun pendidikan kesetraan gender semakin mudah diraih.

Apabila dosen maupun pendidik di seklah mempunyai sensitivitas gender maka sekaligus ada itikad baik dalam mewujudkan keadilan dan kesetaraan gender melalui proses pembelajaran di kelas, penyusunan naskah soal ujian serta dalam perilaku sehari-hari di lingkungan pendidikan.

\section{Metode dan Materi Perkuliahan dan Pembelajaran}

Sebagaimana diketahui, metode pembelajaran secara umum dilaksanakan oleh perguruan tinggi dan persekolahan merupakan metode pengajaran yang lebih mengutamakan transmisi keilmuan klasik, yang memungkinkan terjadinya penerimaan ilmu secara utuh (taken forgranted) yang mampu membebaskan dialog dan diskusi kritis. Sementara itu, permasalahan gender penuh dengan permasalahan kultural yang sulit dituntaskan tanpa melalui proses dialog dan diskusi ilmiah sehingga konsepkonsep penting pendidikan kesetaraan dan keadilan gender secara mudah dapat terserap oleh para siswa.

\section{Bahasa menjadi alat komunikasi dalam Pembelajaran IPS}

Bahasa sebagai unsur terpenting dalam pendidikan yang sensitive gender disebabkan bahwa di dalam bahasa, melalui proses pemilihan kata, intonasi, konstruksi kalimat maupun ujaran yang dipakai dalam berkomunikasi baik secara tulis maupun lisan. Bahasa meliputi bahasa verbal dan bahasa non verbal termasuk bahasa tubuh, diantaranya cara bersalaman, menghormati, memandang yang mengandung makna yang kesemuanya terkadung dalam muatan gender. Menyepelekan peran kebahasaan dalam bidang pendidikan keadilan dan kesetaraan gender sama halnya dengan proses pengabaian unsur penting dalam pendidikan . 
Ratna Puspitasari

\section{Menuju Kesetaraan Gender dalam Pendidikan IPS}

Upaya penghentian ketimpangan atau bias gender pada seluruh aspek kehidupan diantaranya dengan cara memenuhi kebutuhan praktis gender (practical gender needs). Kebutuhan tersebut memiliki kurun waktu jangka pendek serta mudah diketahui hasilnya. Namun upaya dalam melakukan analisa atas keseluruhan ketimpangan dan bias gender seharusnya dilaksanakan dimulai dari jati diri pribadi maupun rumah tangga masing-masing sehingga sampai pada level tinggi yaitu kebijakan pemerintah dan negara, penafsiran keyakinan keagamaan termasuk epistimologi ilmu pengetahuan sosial.

Strategi pokok menuju kesetaraan gender dalam pendidikan IPS diantaranya adlah sebagai berikut:

1. Penyediaan hak atas akses pendidikan IPS yang berkualitas terutama pendidikan di tingkat dasar bagi peserta didik melalui pendidikan persekolahan maupun pendidikan di luar persekolahan;

2. Penyediaan hak atas akses pendidikan yang berkeadilan dan setara bagi segenap warga negara usia dewasa yang belum dapat mengikuti pendidikan di tingkat sekolh maupun lembaga pendidikan tinggi;

3. Peningkatan penyediaan kegiatan pelayanan pendidikan keaksaraan yang diselengggarakan bagi penduduk usia dewasa terutama kaum wanita

4. Peningkatan dengan koordinasi, informasi serta edukasi dalam kegiatan mengarusutamakan pendidikan yang memiliki wawasan gender; dan

5. Pengembangan institusi kelembagaan di bidang pendidikan di tingkat pusat sampai tingkat daerah terkait pendidikan yang memiliki wawasan kesetaraan gender.

6. Pendidikan Islam lebih diprioritaskan pada tujuan memperbaiki sikap dan mentalitas yang diwujudkan pada perbuatan, untuk kepentingan pribadi maupun kepentingan umum yang cenderung bersifat teoritis dan praktis (Daradjat, 1996:28)

7. Pendidikan dianalisa dari aspek psiko sosial (aspek kejiwaan masyarakat) merupakan usaha menumbuhkembangkan sumber daya manusia melalui kegiatan interaksi interpersonal (hubungan individu dengan individu) yang berlangsung dalam lingkup masyarakat terorganisir termasuk didalamnya keluarga dan masyarakat pendidikan pada umumnya. (Syah, 2008:36) 
Perincian atas pernyataan di atas, beberapa prinsip konseptual pendidikan IPS di PTKIN dapat dideskripsikan sebagai berikut:

1. Islam mengutamakan pendidikan sebagai perintah bahkan bentuk kewajiban agama di mana kegiatan belajar mengajar, proses pembelajaran di kelas maupun di masyarakat, serta proses pencarian ilmu merupakan target yang sangat mengandung makna dan memiliki nilai dalam kehidupan umat manusia. Dalam hubungan tersebut, Rasulullah SAW menyebutkan bahwa kegiatan mencari ilmu (hal ini tentu saja berkaitan erat kegiatan belajar mengajar, proses pembelajaran, serta proses pendidikan) merupakan kewajiban utama seluruh muslim baik muslim laki-laki maupun muslim perempuan tanpa perkecualian (Mandy, 1999).

2. Seluruh rangkaian pola aktivitas pembelajaran termasuk di dalam konsep Islam adalah ibadah kepada Allah SWT (QS. Al-Dzariyaat 56). Iman yang selayaknya diejawantahkan dengan amal dan supaya mampu melakukan amalan secara benar dan tepat setiap orang harus memiliki ilmu. Pendidikan menjadi kewajiban individual (baik kaum pria maupun wanita) dan secara kolektif di mana pelaksanaannya dilakukan melalui lembaga pendidikan formal, informal, non formal sesuai dengan tingkat kompetensi masing-masing anggota masyarakat (Mandy, 1999). Karena memiliki nilai ibadah, pendidikan kesetaraan gender dalam Islam selayaknya bermuara pada tercapainya penanaman nilai-nilai keagamaan Iiahiyah pada segenap bangunan sikap, perilaku sertakepribadian peserta didik.

3. Islam menempatkan posisi dan derajat yang lebih tinggi kepada orang-orang yang berpendidikan, kaum terpelajar, sarjana dan ilmuwan. Pendidikan mempunyai peranan penting dan menjadi kunci strategis dalam menciptakan kaum berpendidikan yang terdidik, kaum terpelajar, kaum intelektual, para ilmuwan, para ahli atau pakar serta para sarjana.

4. Seluruh kegiatan pembelajaran dan aktivitas pendidikan dalam konsep maupun struktur ajaran agama Islam berlangsung seumur hidup dan sepanjang hayat, tanpa mengenal batas usia (long life education).

5. Seluruh pola kegiatan pembelajaran dalam konstruk Islam cenderung inovatif, dialogis dan terbuka. Islam mampu menerima kekayaan ilmu pengetahuan produk berbagai lembaga pendidikan dari Barat maupun Timur selama hal itu 
Ratna Puspitasari

bermanfaat bagi peningkatan mutu intelektualitas dan kreativitas manusia (Mandy, 1999).

Konsepsi Islam mengenai manusia teraplikasi pada konsep pendidikan Islam di Jurusan Tadris IPS IAIN Syekh Nurjati sehingga menghasilkan pendidikan yang berkeseimbangan. Prinsip keseimbangan ini menjadi ciri khas pendidikan Islam di PTKIN, mengacu pada keseimbangan rohani dengan jasmani, individu dengan masyarakat, dunia dengan akherat, termasuk laki-laki dengan perempuan.

Pendidikan Kesetaraan gender menjadi alat strategis dalam transformasi social budaya masyarakat modern. Budaya patriarkhi masih berkembang dan terkait erat dengan proses pembelajaran antar generasi, di mana ketimpangan gender melalui proses pendidikan yang kurang adil dan setara (Mandy, 1999).

\section{SIMPULAN}

Mata kuliah Kajian kesetaraan gender dalam PIPS mengajarkan Islam laki-laki dan perempuan itu berpasangan sebagai mitra sejajar dan bukan berhadapan. Rumusan perkuliahan tersebut adalah kunci untuk memahami konsep gender dalam agama Islam yang mewujudkan konsekuensi penting. Perumusan pembelajaran kesetaraan gender selanjutnya memunculkan rumusan lain yang berhubungan dengan hak dan kewajiban, kesetaraan dan keadilan di antara laki-laki dengan perempuan dalam upaya saling menguatkan dan melengkapi.

Kajian Kesetaraan Gender dalam Islam termasuk didalamnya perkara muamalah. Dalam muamalah segala yang tidak adil adalah larangan.Perubahan jaman mrmunculkan perubahan konsep. Perempuan sebagaimana lelaki di masa kini didukung dalam melakukan banyak hal bahkan gender Islam pun demikian selama tidak menghilankan atribut keIslamannya.

Keadilan sebagai sebuah prinsip diterapkan dalam pembelajaran kesetaraan gender. Diskriminasi pada perempuan berbanding terbalik dengan prinsip itu, sehingga perbedaan sifat psikologis dan biologis tidak menjadikan keduanya dibedakan dan didiskriminasi. Implementasinya adalah prinsip keadilan dan kesetaraan dalam pembelajaran Ilmu Pengetahuan Sosial dalam artian bukan menyamaratakan laki=laki dengan perempuan di segala bidang karena secara kodrati keduanya berbeda. 


\section{DAFTAR PUSTAKA}

Acee Suryadi, Ecep Idris. 2004. Kesetaraan Gender dalam Bidang Pendidikan. Jakarta: PT Genesindo

Achmad Muthia'in. 2001. Bias Gender dalam Pendidikan, Surakarta: UMS

Al-Attas, Syed Muhammad al-Naquib, 1984, Konsep Pendidikan dalam Islam. Diterjemahkan oleh Haidar Bagir, Bandung: Mizan.

Al-Bari, Haya Binti Mubarak, 1997, Mausu'at al-Mar'ah al-Muslimah. Alih bahasa: Amir Hamzah Fachruddin. Jakarta: Darul Falah. Cet. I.

Al-Kurdi, Ahmad al-Hajji, 1995, Ahkam al-Mar'ah fi al-Fiqh al-Islamiy.Alih bahasa: Moh.Zuhri dan Ahmad Qorib. Semarang: Dina Utama. Cet. I.

Daryo Sumanto, 2004. Isu Gender dalam Bahan Ajar. Jakarta: Akses Internet

Dwi Narwoko dan Bagong Yuryanto. 2004. Sosiologi Teks Pengantar dan Terapan. Jakarta: Kencana Prenada Media Group.

Elfi Muawanah. 2009. Pendidikan Gender dan Hak Asasi Manusia. Yogyakarta: TERAS

Fakih, Mansour, 1997, Analisis Gender dan Transportasi Sosial, Yogyakarta: Pustaka Pelajar.

King Abdul Aziz University, 1997, First World Conferse on Muslim Education Reccomendations, Jeddah \& Mecca Al-Munawarah: King Abdul Aziz University.

Mac donald, Mandy, dkk, 1999, Gender dan Perubahan Organisasi: Menjembatani Kesenjangan antara Kebijakan dan Praktik. Alih bahsa: Omi Intan Naomi. Yogyakarta: Pustaka Pelajar.

Moh, Roqib, Pendidikan Perempuan, (Yogyakarta: Gama Media, 2003)

Moh, Roqib. 2003. Pendidikan Perempuan. Yogyakarta: Gama Media

Rajab, Ibn Al-Hambali, The Excellence of Knowledge, , Birmingham: Darussunnah Publisher,Kalamullah. com, ebook.

Shaikh, N.M., 1991, Woman in Muslim Society. New Delhi: Kitab Bhavan. Cet. I.

Tafsir, Ahmad, 2013, Ilmu Pendidikan Islami, Bandung: Remaja Rosdakarya, Cet. II.

Umar, Nasaruddin, 1999,Kodrat Perempuan dalam Islam, Jakarta: Lembaga Kajian Agama dan Gender. 